\title{
O MEDO E A CIDADE: NOTAS SOBRE MURILO RUBIÃO E ESPINOSA
}

\section{Luiz Carlos Montans Braga ${ }^{1}$}

\section{Resumo}

O artigo tem por objetivo analisar a relação entre o afeto medo e o conceito de avesso da política, que faz da cidade deserto ou solidão. Este tema será abordado por meio do estudo de um conto de Murilo Rubião, intitulado 'A cidade ', bem como de alguns conceitos espinosanos que dialogam com o conto. O método é o da análise em detalhe das fontes primárias, eventualmente com auxílio de comentadores. $\mathrm{O}$ artigo conclui pela importância da literatura e da filosofia - bem como do diálogo entre ambas - como áreas que permitem aguçar o olhar que faz análises sobre a seara política. Especificamente, o artigo mostra, pela análise das obras dos dois autores, que o afeto medo pode ser termômetro para aferir o avesso da política ou a morte da cidade. Os autores, ao final, mostram-se lentes potentes para ler a política e a cidade, o que aponta para a necessidade de mais pontes entre uma e outra área.

Palavras-chave: Murilo Rubião. Espinosa. Afetos. Medo. Política.

\section{INTRODUÇÃO: O REALISMO DE MURILO RUBIÃO}

Günther Anders, ao escrever sobre a literatura de Kafka, afirmou que o autor Tcheco não faz alegoria ou registros fantásticos. Sua ficção, por deslocamento, isto é, por metáfora ${ }^{2}$, descreve o real tal qual ele é.

Por outros termos, apenas as lentes da ficção poderiam, de fato, fazer o leitor enxergar o real em seu absurdo constitutivo por meio do recurso à surpresa, ocasionada em razão do deslocamento produzido. $\mathrm{O}$ absurdo não é, pois, a ficção que aparentemente desloca as leis da lógica cotidiana, mas a realidade que ela descreve. O recurso à metáfora é a ferramenta do autor para fazer que o leitor tenha acesso ao mundo que não pode ser visto pelo olhar do senso comum. Nesse sentido, o realismo fantástico é uma literatura realista, pois usa a metáfora, no sentido de Ricoeur, para fazer ver (RICOEUR, 2005, p. 17-75; ANDERS, 2007).

Murilo Rubião já era autor maduro e publicado quando leu Kafka (WERNECK, Humberto, 2016, p. 3).

\footnotetext{
${ }^{1}$ Doutor em Filosofia (PUC SP - 2015). Participa do Grupo de Estudos Espinosanos (USP). E-mail: montansbraga@hotmail.com ${ }^{2}$ Ricoeur, em estudo sobre Aristóteles (RICOEUR, 2005, p. 17-75), lembra que a metáfora é definida em termos de movimento. 'Meta' é o mesmo que 'além de', e 'phora' vem da Física (III, 1, 201 a 15; V, 2, 225 a 32 b2) de Aristóteles, e significa "uma mudança segundo o lugar”. A metáfora necessita da metáfora para ser definida. Ela é, segundo Ricoeur, um empréstimo; o sentido emprestado opõe-se ao sentido próprio; recorre-se a metáforas para o preenchimento de um vazio semântico; a palavra emprestada toma o lugar da palavra própria ausente, caso esta exista (RICOEUR, 2005, p. 31). Aqui, seguindo Anders (ANDERS, 2007), entende-se que Kafka tem um discurso todo ele metafórico porque coloca no lugar do discurso "normal" um outro, provocando
} 
Portanto, praticou literatura semelhante à kafkiana antes de conhecer o famoso autor Tcheco. É da mesma linhagem de autores que usam o fantástico na literatura para fazer descrições precisas acerca dos absurdos do mundo. Essa também a hipótese de Modesto Carone, na mesma linha de Anders, ao ler o autor tcheco como escritor que recorre à metáfora para descrever o real (CARONE, 2008; ANDERS, 2007).

Em Conversas com Kafka $a^{3}$ o escritor Gustav Janouch narra episódio que pode ser uma chave para a análise da obra de Kafka e, igualmente, de Murilo Rubião. Ao visitar uma exposição de pinturas francesas numa galeria de Praga, Kafka pôde observar várias obras de Picasso. Estava acompanhado pelo então jovem escritor Gustav Janouch, de quem foi mentor. Modesto Carone, citando e analisando o texto de Janouch, escreve:

Janouch comentou que o pintor espanhol distorcia deliberadamente os seres e as coisas. Kafka respondeu que Picasso não pensava desse modo: 'Ele apenas registra as deformidades que ainda não penetraram em nossa consciência'. Com uma pontaria de mestre, acrescentou que 'a arte é um espelho que adianta, como um relógio', sugerindo que Picasso refletia algo que um dia se tornaria lugar-comum da percepção - 'não as nossas formas, mas as nossas deformidades' (CARONE, 2008, p. 197).

"Registrar as deformidades". Fazê-lo é, em alguma medida, descrever. Picasso faz a mimese do que vê, é certo. Porém, do que vê com as lentes de artista. O que para o observador da obra aparece como deformação, na verdade é o deslocamento que o artista opera para mostrar o que ele efetivamente vê. Então o real retratado é diverso do real visto "com os próprios olhos", isto é, com os olhos não afinados do observador comum. Há aí outro ver, resultado de outro modo de olhar, que faz ver além do que se enxerga. A operação é filosófica no mesmo sentido do ver (perceber) o sol que nasce a leste e se põe a oeste e do enxergar, como os olhos da mente, o sol que queda inerte. Mas a finura da arte de Picasso, na interpretação de Kafka, está em enxergar com o olhar que o deslocamento faz ver, adiantando o relógio do que será mais claro à consciência - talvez - no futuro. Kafka, assim como Murilo Rubião, fazem o mesmo com sua arte.

Na obra muriliana, o absurdo é o real, e no fio desse aparente paradoxo seus contos navegam. Quando o absurdo aparece na escrita, o faz com trajes de normalidade. Os acontecimentos fluem num fantástico encarado pelos personagens como absolutamente dentro da normalidade.

Essa interpretação dos contos de Murilo Rubião aqui proposta se apoia também em comentário de Carlos Drummond de Andrade em carta a ele endereçada, na qual o poeta mineiro afirma que um dos traços marcantes da literatura muriliana seria o de fazer passar por normal o que há de mais estranho, explicitando exatamente este traço do mundo, seu nonsense completo. Escreve Drummond: "E por mais absurdas que sejam as novas relações estabelecidas por V. entre as coisas do homem, a verdade é que elas não são mais absurdas do que as condições de vida normal, controlada pela razão: eis a lição amarga que se tira de sua sátira, tão poética e tão

um deslocamento de sentidos que faz ver. E, para Anders, tal deslocamento causa espanto no leitor. Murilo Rubião opera na mesma chave - eis uma hipótese de leitura a ser trabalhada por este artigo.

${ }^{3}$ Citado a partir de CARONE, 2008, p. 197. 
rica de invenção." (DRUMMOND, 2016, p. 36).

Eis o pano de fundo cujo objetivo foi o de estabelecer conceitualmente a chave em que operam os contos de Murilo Rubião. Passa-se, nas linhas a seguir, à descrição da proposta mais central do artigo.

\section{O CONTO ‘A CIDADE’ E SUA DISTOPIA OU MURILO RUBIÃO POLÍTICO}

O artigo intenta, doravante, explicitar alguns traços de filosofia política presentes em um conto de Murilo Rubião. Na interpretação aqui proposta, o conto procura mostrar o que se pode chamar de avesso do que seja uma cidade. Tal avesso de cidade, Espinosa, no Tratado Político (TP V 4 p.45) ${ }^{4}$, nomeia solidão ou deserto. A distopia descrita no conto se assemelha a este conceito espinosano, em contraposição ao conceito de cidade, como se analisará em momento oportuno.

A leitura que o artigo propõe terá como fundamento filosófico-político alguns conceitos espinosanos presentes especialmente no Tratado político. Procurar-se-á ler o conto de Rubião utilizando conceitos ligados ao de cidade, e de seu avesso, segundo Espinosa. O arsenal conceitual espinosano será, em certos momentos, ferramenta de análise da distopia proposta por Rubião no conto 'A cidade'. Porém, haverá análise dos conceitos espinosanos especificamente no item (4) deste artigo, quando ficará mais clara a ligação entre os temas presentes no conto e aqueles presentes na obra de Espinosa. Literatura e filosofia se encarregam de mostrar, cada qual à sua maneira, o avesso da política.

O conto objeto de análise é magro, como a obra completa de Rubião, que ocupa menos de trezentas páginas na edição recente da Companhia das Letras (RUBIÃO, 2016). Desenvolve-se em envolventes sete páginas.

Tem como epígrafe, o que é praxe nos contos de Rubião, uma passagem do antigo testamento: "O trabalho dos insensatos afligirá aqueles que não sabem ir à cidade (Eclesiastes, X, 15)." (p. 29) $)^{5}$. Parece ser o caso

\footnotetext{
${ }^{4}$ Para facilitar a consulta a qualquer edição da obra de Espinosa, adotar-se-á o seguinte modo de citação: As obras de Espinosa que serão mencionadas se encontram na edição crítica de Carl Gebhardt (ESPINOSA. Spinoza Opera. Ed. de Carl Gebhardt. Heidelberg: Carl Winter, 4 vols, 1972 [1ª ed. 1925]). Quando citada a edição de Gebhardt, citar-se-á: G, seguido do tomo em romano e da página em arábico. As traduções consultadas são as seguintes: ESPINOSA, 1998. ESPINOSA, 2008. ESPINOSA, 2009. ESPINOSA, 2003. Para a Correspondência, EP, seguida do número da carta em arábico e após o número da página, em arábico. Para a Ética e o Tratado político, usar-se-á a seguinte abreviação: para a Ética E, seguido da parte em romano, D para definições, Def af para definição dos afetos, A para axiomas, Dem para demonstrações, P para proposições, Cor para corolários, Ap para apêndices, L para lemas, Esc para escólios, Post para postulados, Explic para explicações. Um numeral arábico indicará o número de cada um desses itens. Após, a página em arábico. Para o TP, numeral romano indica o capítulo e numeral arábico indica o parágrafo. Após, a página em arábico. Para o TTP, numeral romano indica o capítulo. Após, a página em arábico. Assim se procede para facilitar a consulta a qualquer edição das obras de Espinosa, mesmo que seja à custa do não cumprimento estrito das regras de citação da ABNT.

${ }^{5}$ Todas as citações com indicação apenas da página se referem a RUBIÃO, 2016, conto 'A cidade'.
} 
do protagonista do conto, nomeado apenas Cariba ${ }^{6}$. Único passageiro de um trem que se destinava a uma cidade maior, como descrito no início do conto, permaneceu, como o trem, [...] "indefinidamente na antepenúltima estação." (p. 29).

De início, o personagem pensou que algum evento, como um acidente, teria sido a causa da parada. Mas ela se demorava muito. Resolveu então indagar ao funcionário que examinava as passagens se tamanha demora se dava em razão de ser ele, Cariba, o único passageiro da composição. O protagonista já estava, neste momento, sob a égide da desconfiança e do medo, afetos que ocupam todos os poros do conto, somando-se ao absurdo e ao inusitado.

O empregado não o respondeu de forma direta. Apenas apontou o morro em que se dispunham casinhas brancas, às dezenas.

À pergunta, "Belas mulheres?", teve Cariba a resposta "Casas vazias". Ao constatar que tinha diante de si um "cretino" (p. 30), apanhou as malas e se dispôs a subir o morro até o povoado apontado pelo funcionário.

Do alto do morro com as casinhas, dentro das quais não havia ninguém, avistou a cidade no vale. Tão grande quanto a que buscava. Pensou que os homens, bem como as belas mulheres, por que não, deveriam se encontrar lá embaixo.

A recepção do protagonista na cidade foi estranha. Os moradores, diz o texto, observavam Cariba com desconfiança. Cariba pensou que tal tratamento derivava de seus trajes, que poderiam parecer aos moradores algo exóticos, ainda que ele os usasse comumente para viajar e nunca causaram qualquer problema (valises de couro de camelo, paletó xadrez, calças de veludo azul). Na intenção de desfazer qualquer mal-entendido, indagou: "Que cidade é essa?" (p. 30). O tom da pergunta foi o de máxima cordialidade. Afinal, Cariba percebeu que o tratavam com desconfiança.

A reação dos "cidadãos" foi inusitada. "Pegaram-no com violência pelos braços e o foram levando, aos trancos, para a delegacia de polícia: -É o homem procurado - disseram ao delegado, um sargento espadaúdo e rude." (p. 31). Aqui, os termos delegado, expressão designadora de função do âmbito civil, e sargento, termo militar, se sobrepõem, o que explicita se tratar de uma coisa só. O clima de guerra e o investigatório se somam num delegado que é sargento. O clima é policial, num sentido amplo.

À pergunta do delegado a Cariba, "O que veio fazer aqui?", o protagonista respondeu "Nada" (p. 31). A resposta do delegado foi ainda mais surpreendente: "Então é você mesmo" (p. 31).

Afinal, diz o delegado, como pode alguém ir a uma cidade desconhecida sem nenhum objetivo, exceto se

\footnotetext{
${ }^{6}$ Segundo o HOUAISS: Iba - elemento de composição antepositivo, do tupi i'wa (oxítono) 'fruta, fruto'. [...]. Car - elemento de composição antepositivo, do adj. lat. căruss,a,um'caro, querido' e 'caro de preço, a que se atribui um grande valor. [...]. Ou seja, o protagonista tem como nome o que se poderia designar como "querido-fruto". Dicionário HOUAISS. Disponível em: http://houaiss.uol.com.br. Acesso em: 22 AGO 2016.
} 
for turista? Cariba afirma que não é turista, e quer saber do delegado, ou de qualquer um, onde está. Ao que lhe respondem não poderem dizer naquele momento, pois isso poderia prejudicar as investigações (p.31).

Que se analise o que há até este primeiro movimento do conto. Rubião descreve um protagonista quase vazio. Sabe-se que se chama Cariba, o que, pelo Houaiss ${ }^{7}$, significa algo como "querido-fruto". Nada mais se sabe sobre ele, exceto que está na composição como único passageiro e o trem não mais avança, chegando à antepenúltima estação, não ao destino. E esse absurdo, não se chegar ao destino programado, é dado como normal, não havendo qualquer explicação, de qualquer pessoa que seja, sobre o inusitado fato. Cariba navega na dúvida.

Ao seguir a informação do empregado, que é uma não-informação, isto é, apenas um apontar casinhas no alto do morro, chega às tais construções. Encontra as casas fechadas. Após avistar a cidade no vale, de uns vinte mil habitantes, desce até ela. Chega como um estranho e é observado com desconfiança. À primeira pergunta, "Que cidade é esta?", teve como resposta a violência. Física e psíquica. Pegaram-no e o levaram à delegacia, símbolo de investigação, crime, força policial, ou seja, tudo o que deveria ser exceção ao se tratar de uma cidade.

Portanto, moradores desconfiados, ambiente próprio ao afeto medo. Medo do diferente, do que não estava lá até então, do que pode vir de um homem que não estava sendo esperado. E à primeira pergunta, a resposta violenta, bem como a acusação. Após indagar a razão pela qual as casas do morro estavam fechadas, tem como resposta o mesmo ambiente acusatório e sombrio da cidade em que chegou: "Se não tomássemos essa precaução você não desceria" (p. 31). As casas brancas eram, pois, um ardil. O ambiente de medo e de acusação, inquisitorial portanto, já formara o clima desde a parada do trem. Cariba, entretanto, não o sabia. Porém, o sentido do clima de ardil e de medo somente se apresenta por completo - paradoxalmente no terreno do absurdo, o que faz que o sentido dado pelo delegado às casas brancas não passe de uma falta de sentido, acentuando o ambiente de nonsense no momento mesmo em que se quer dar sentido ao clima acusatório - depois de Cariba descer ao vale, à cidade.

Que cidade é esta em que vige a desconfiança, o ardil, o medo e a acusação? É uma não cidade, o local em que o poder se exerce fundado no medo e no clima acusatório. Analisar-se-á este ponto, pelas lentes espinosanas, em momento oportuno. Antes, segue-se o veio do conto para mostrar a que ponto se chega na "cidade" em questão. É claro, pela hipótese que se segue nesta análise, que Rubião tem por objetivo chegar ao que tão precisamente viu o arguto analista acima citado, Carlos Drummond de Andrade, ao afirmar que "[...] por mais absurdas que sejam as novas relações estabelecidas por V. entre as coisas do homem, a verdade é que elas não são mais absurdas do que as condições de vida normal, controlada pela razão: eis a lição amarga que se tira de sua sátira, tão poética e tão rica de invenção." (DRUMMOND, 2016, p. 36).

\footnotetext{
${ }^{7}$ Ver nota anterior.
} 
E nesse veio caminha o conto exponenciando o clima de medo e de acusação - clima das cidades atuais, do Estado ausente nas periferias, excessivamente burocrático e kafkiano (muriliano?) em todos os poros da vida, ameaçador ao cidadão, quando não gerador do medo e da solidão?

Cariba, então, compreendendo (?) a razão das casinhas brancas, a isca que o fez descer ao inferno então imaginado como cidade, se depara com os disparates do delegado. Este clama, aos gritos, pelas testemunhas. A primeira testemunha, ao olhar para Cariba, agora "o preso" (p. 31), afirma "não ter medo da sua cara" (p. 31). Ao que o sargento-delegado responde à testemunha - descrita como "[...] um homem de rosto chupado [...]" (p. 31) afirmando que pouco importa a sua coragem. A resposta da testemunha à pergunta que se quer objetiva - "Cinjase ao que for interrogado e responda logo se conhece este sujeito. " (p. 31) - é de uma ambiguidade desconcertante. Afirma simultaneamente duas coisas, a saber, que nunca teria visto Cariba antes, porém teria a impressão de que fora ele que o abordara na rua, pedindo informações sobre os costumes da cidade e posteriormente desaparecendo. Curioso o contraponto entre a exigência de objetividade do cingir-se ao que for indagado e a resposta explicitamente dúbia. O medo não floresce exatamente onde não há certezas mínimas, um mínimo chão? Está-se neste clima, que se aprofunda na medida em que todas as testemunhas, chamadas pelo sargento de "os outros idiotas" (p. 32), nada esclarecem. Sequer sabem algo sobre Cariba. A ponto de terem como única coisa em comum uma espécie de opacidade: "Só num ponto estavam de acordo, tanto os que lhe ouviram a voz ou the divisaram apenas o semblante: não sabiam descrever seu aspecto físico, se era alto ou baixo, qual a sua cor e em que língua thes falara." (p. 32). Ou seja, o ponto em que as testemunhas estavam de acordo era precisamente um não-saber completo.

Até este momento, o que há, sob o recheio do absurdo, é a denúncia muriliana de como se mostra uma cidade que, de tal maneira coloca seus iguais sob suspeição, e especialmente os diferentes, que o que há é um rol de termos ligados a clima policialesco, o avesso da política. $\mathrm{O}$ medo é o afeto predominante. $\mathrm{O}$ clima investigativo, inquisitorial, dá o tom dos atos de todos. Outro protagonista temático no conto é, eis uma hipótese, o delegadosargento, e tudo o que deriva do clima investigativo que impõe.

Que se volte ao veio do conto, para, após, fazer-se um segundo movimento de análise.

Aos gritos, o delegado chama pela prostituta Viegas, outra testemunha, a qual, segundo ele, "sabe" (p. 32), diferentemente das demais.

A prostituta narrou ao delegado que Cariba tentara agarrá-la, que teria dito a ela para não temer a polícia "não é necessária a polícia" (p. 33) -, e que teria dito, obrigando-a a encostar os ouvidos nos lábios de Cariba: "É preciso conspirar." (p. 32). Viegas, a prostituta, ainda diz ao delegado que advertiu Cariba acerca do perigo da polícia da cidade, por ser rigorosa.

Porém, Cariba, segundo o narrador, simplesmente sentiu inveja de quem teria possuído em seus braços 
aquele belo corpo (p.33).

O policial pergunta a Viegas se ela se lembraria de Cariba como sendo o homem que a agarrou. Ela, porém, desconfirmando o que acabara de dizer, afirma que não se lembrava do rosto dele, mas categoricamente, não obstante isso, diz que Cariba e quem a teria agarrado seriam a mesma pessoa (p. 33).

Diante desta contradição, o delegado ficou satisfeito. Surpreendentemente, visto que outrora disse às demais testemunhas: "Cinja-se ao que for interrogado e responda logo se conhece este sujeito. " (p. 31). Essa ambiguidade de perguntas sem sentido seguidas de respostas com menos sentido faz parte da descrição de um clima em que o medo e a acusação são, por esses recursos, levados ao máximo. Não há, com efeito, certeza acerca de nada, e tudo isso passa por normal a todos, exceto, em alguns momentos, a Cariba, o único que mantém pensamento e esperança em algum grau.

Novamente o delegado interroga todas as testemunhas, para saber se Cariba seria de fato o homem procurado, mas ficam em silencio, exceto Viegas, que afirma: "Sim, é ele." (p. 33).

Uma frase absurda, em meio aos demais absurdos que se vão sobrepondo uns aos outros, é dita então pelo sargento: "O telegrama da Chefia de Polícia não esclarece nada sobre a nacionalidade do delinquente, sua aparência, idade e quais os crimes que cometeu." (p.33). Porém, conclui, ao contrário do que seria lógico ou coerente: "Diz tratar-se de elemento altamente perigoso, identificável pelo mau hábito de fazer perguntas e que estaria hoje neste lugar." (p.33).

Delegado de polícia, testemunhas cretinas, prostituta que afirma saber sem ter qualquer elemento para tal e, especialmente, a relação entre "elemento altamente perigoso" (p. 33) e o "mau hábito de fazer perguntas" (p. 33). Ou seja, a paz da cidade da narrativa é a paz dos cemitérios, em que o direito de questionar, ou a própria possibilidade da existência de qualquer questionamento, é definidor de conduta criminosa.

Mas Cariba ainda detém um resto de indignação. E afirma ao sargento: "Nada disso faz sentido. Não podem me prender com base no que acabo de ouvir. Cheguei aqui há poucas horas e as testemunhas afirmaram que me viram, pela primeira vez, na semana passada!" (p. 33-34). Ao que o delegado respondeu categoricamente, mas sem qualquer amparo na lógica ou no bom senso, que o comunicado do setor de segurança seria claro, isto é, "O homem chegará dia 15, isto é, hoje, e pode ser reconhecido pela sua exagerada curiosidade." (p. 34).

O rol de absurdos se exponencia no caminho final do conto. Encerrados os interrogatórios pelo policial já não mais é um delegado-sargento -, afirma que os depoimentos colhidos até ali seriam suficientes para incriminar Cariba. Porém, não era o caso de precipitação. Conclusão: aguardaria o aparecimento de alguém que reunisse indícios de maior culpabilidade contra si e que livrasse Cariba das acusações que sobre ele pesavam (p. $34)$.

O clima policialesco e absurdo - seriam a mesma coisa? - chega ao limite quando Cariba indaga se 
permanecerá preso enquanto o eventual verdadeiro criminoso não aparece para o livrar das acusações. Ao que o delegado (agora novamente o delegado) responde: "[...] ficaria encarcerado até a captura do verdadeiro criminoso." (p. 34). E se o culpado simplesmente não existisse? Pergunta sem resposta, como tudo o mais no conto.

Passam-se cinco meses e Cariba não mais espera, diz o narrador em terceira pessoa, sair da cadeia. Os homens que passam na rua, amedrontados quando o veem, apressam o passo.

A iminência de qualquer pergunta vinda dos homens que passam é seguida de um abrir de bocas, das quais nada sai. Arrependem-se da intenção e nada indagam (p.34). Afastam-se rapidamente. Aparecem mulheres, aparece Viegas, a prostituta, que insiste em dizer "É você" (p. 35). E afirma o protagonista: "Quando ela [Viegas] se despede - o corpo tenso, o suor porejando na testa - Cariba sente o imenso poder daquela prisão." (p. 35).

Ao final do conto, caminhando dentro da noite, na prisão, ao avistar o guarda, tendo Cariba um fio de esperança - "uma débil esperança" (p. 35) -, indaga: "Alguém fez hoje alguma pergunta?". Ao que o guarda responde: "Não. Ainda é você a única pessoa que faz perguntas nesta cidade." (p. 35).

Passa-se à análise desse segundo movimento do conto.

A passagem de Cariba pela cidade do vale, após ser atraído pelas casinhas brancas e vazias e descer o morro, é a passagem por um ambiente que se poderia definir como de medo capilarizado.

O único local mencionado no conto, após a desconfiança geral dos moradores em face de Cariba e de sua prisão, depois de caminhar pelas ruas, é a delegacia. Nela, o protagonista é objeto de indagações absurdas, de testemunhas cretinas, da incoerência de tudo e de todos. O medo é o afeto predominante, em Cariba e em todos os demais. A polícia, nas palavras de Viegas, é muito rigorosa. Após a prisão de Cariba, não se sabe sequer o crime que cometeu, lembrando a situação do protagonista de outro clássico, Josef K., personagem vazio de O Processo, de Franz Kafka.

O clima de medo se fixa até mesmo na personagem aparentemente mais flexível, sensual, violadora de regras - por ser prostituta -, do conto: Viegas. Ela aparece com "[...] o corpo tenso, o suor porejando na testa [...]" (p. 35) ao visitá-lo na prisão, o que faz que Cariba sinta o poder imenso da prisão. Ou seja, o poder paralisador, avesso ao político, do afeto medo.

Pois é o afeto medo aquele que Espinosa estabelece como sendo o que diminui a potência, a vitalidade dos cidadãos. $\mathrm{O}$ afeto esperança, um afeto alegre que deve predominar na cidade, é precisamente aquele sentido, ao que indica o conto, apenas por Cariba. E isso num grau quase nulo. Nos demais personagens, aparece o medo, o assombro, a falta de conhecimento, a confusão, o desejo acusatório, a desconfiança.

Os demais "cidadãos", ao se aproximarem de sua prisão, apenas abrem a boca para dizer algo e sequer falam. Após, fogem, com medo. O fio de esperança está concentrado apenas em Cariba. E é "uma débil esperança" 
(p. 35). Cariba personifica uma indignação - que se lembre de sua possível frase no ouvido de Viegas, "É preciso conspirar." (p. 32) - que não se dissemina, não dá frutos políticos. O que se dissemina na "cidade" do conto é apenas o medo. E a indignação sequer pode avançar em blocos de pessoas com o mesmo sentimento lutando contra a opressão desse afeto triste. $\mathrm{O}$ medo vence, e o único a fazer perguntas é Cariba, como atesta o final do conto. Desde sempre, ele é o único a se indignar, dentro do possível, que é parco, e é o único a fazer perguntas, o que é crime.

Tem-se então no conto de Murilo Rubião não a narrativa do que seja uma cidade, mas uma distopia, em que o protagonista oculto é o medo. Há o que se passa a analisar, com instrumental espinosano, isto é, solidão, deserto, paz dos cemitérios, o que aponta para exigências do que possa ser definido como cidade. Não se trataria, segundo o autor holandês, de paz como mera ausência de guerra (HOBBES, 1997, p. 109), mas de paz como força do ânimo, como potência individual em exercício.

Algumas notas sobre tais conceitos, a seguir, o que mostrará a proximidade entre a literatura muriliana e a filosofia espinosana.

\section{ESPINOSA E A CIDADE COMO O AVESSO DA SOLIDÃO}

O prefácio ao Tratado político, na verdade a carta 84 acrescida ao tratado pelos organizadores das obras de Espinosa publicadas postumamente, é uma espécie de mapa para o leitor do livro.

Com efeito, Espinosa escreve ao destinatário anônimo ${ }^{8}$ que estava empenhado em obra útil, a saber, o Tratado político. Mostra então ao destinatário os caminhos já percorridos e os que ainda estavam por ser realizados. Seis capítulos do tratado já estavam concluídos na ocasião ${ }^{9}$. E passa Espinosa a fazer um sumário que indica os seguintes caminhos: capítulo primeiro contendo uma introdução à obra; o segundo tratando do direito natural; o terceiro dos poderes soberanos; o quarto acerca dos assuntos políticos que dependem dos poderes soberanos; o quinto, do fim mais elevado e último que uma sociedade pode ter em vista; o sexto, de qual a ratio de um imperium (Estado, em tradução precária) monárquico para que não resulte em tirania. Escreve, por fim, que se ocupa na ocasião do capítulo sétimo, no qual esmiúça as instituições da monarquia bem ordenada. E aponta para o que faria após, a saber, trataria do imperium aristocrático e do popular (democrático [ populare imperium - G IV 336]), para, ao final, escrever acerca das leis e outros assuntos relativos à política (TP Pref pp. 3-4). Sabe-se que Espinosa findou as reflexões acerca do imperium aristocrático, mas deixou incompleto o tratamento da democracia, bem como as questões gerais respeitantes às leis e à política.

O que há de surpreendente nesta ordem é o tema e o lugar do capítulo quinto. Ou seja, "[...] qual o fim

\footnotetext{
${ }^{8}$ Sobre o destinatário anônimo, ver: ESPINOSA, 1998, p. 413, nota 442.

${ }^{9}$ A Carta é provavelmente do segundo semestre de 1676. Ver: ESPINOSA, 1998, p. 413, nota 442.
} 
último e mais elevado que uma sociedade pode ter em vista [...]” (TP Pref p. 3). Por que não tratar deste tema em cada um dos capítulos referentes aos regimes, para mostrar que o democrático é o que mais satisfaz a natureza humana, ecoando o Tratado Teológico-político e o refinando? Uma hipótese passa pelo argumento seguinte: é claro, pelo texto do Tratado Teológico-político, que Espinosa mira a democracia como o mais natural dos regimes, isto é, aquele que mais satisfaz a natureza humana, na medida em que ninguém quer ser governado e todos querem governar. Trata-se do regime de melhor equação entre homens como potência, de um lado, e desejo de mando e de não ser comandado, de outro (TTP XVI pp. 240-242). Entretanto, mesmo em regimes como o monárquico, no qual há o governo de um, Espinosa se esforça por mostrar que o que dá potência ao rei é a multidão (TP VII 31 p. 85). Um apenas, com sua potência isolada, não tem como governar, pois a "[...] potência de um só homem é, de longe, incapaz de sustentar tão grande peso." (TP VI 5 p. 49). Daí a necessidade de uma distribuição da potência do soberano para os conselhos, cujos membros devem ser numerosos. Como propõe Espinosa, "[...] os conselheiros do rei, que estão próximos ou logo a seguir a ele em dignidade, devem ser bastante numerosos [...]." (TP VI 15 p. 53). A questão do melhor gênero de estado civil deve ser iluminada pela questão que é objeto do capítulo quinto, o qual antecede os capítulos em que os regimes passarão a ser objeto direto do tratado, ou seja, capítulo sexto e seguintes.

Em suma, a hipótese é a de que o capítulo quinto está localizado estrategicamente entre os capítulos gerais (Desde a Introdução até o capítulo quarto) e o primeiro capítulo que tratará da questão clássica dos regimes (monárquico, aristocrático e democrático), depois do qual virá o tratamento dos demais regimes. Interessa destacar, portanto, que o capítulo quinto mostra que há uma questão de fundo a iluminar qualquer análise de gêneros de estado civil ou de tipos de regime, a saber, a do fim maior e mais elevado que uma sociedade pode ter em vista, independentemente do regime. É certo que no regime democrático há o melhor para as potências individuais. Espinosa procurará mostrar, entretanto - daí o lugar do capítulo quinto na economia do texto do Tratado político, pois o que ali foi desenhado vale para qualquer dos regimes a serem tratados na sequência -, como a fortaleza de ânimo dos súditos-cidadãos pode ser garantida da melhor maneira, em cada gênero de estado civil, em razão de suas peculiaridades.

Mostrar-se-á, a seguir, a importância dos conceitos espinosanos presentes neste capítulo para os temas que foram trabalhados anteriormente no conto de Rubião. A frequência dos afetos alegres, bem como, correlato a isso, a intensidade do direito natural dos súditos-cidadãos na cidade, irromperão como sendo a razão da importância do referido capítulo. E não apenas os afetos em geral, mas aqueles ligados ao que se poderia chamar de política de realização máxima do desejo dos membros do corpo político e de seu direito natural individual. E, outro lado da moeda, o que significa a não realização destes desejos, e que se poderia chamar de situação em torno de um grau zero de potência. Trata-se da questão que Espinosa coloca nos seguintes termos: a diferença, de 
enorme importância para a reflexão política, entre paz como ausência de guerra e paz como fortaleza de ânimo.

Na famosa Carta 50 a Jarig Jelles, Espinosa explicita o fosso que o separa da filosofia política hobbesiana ao dizer que mantém sempre o direito natural (Ep. 50, p. 398). De fato, Hobbes entende, pelos mecanismos de transferência de direitos naturais dos súditos-pactuantes ao soberano, por intermédio dos conceitos de pessoa (Leviatã I 16 p. 135) e representação, que o poder soberano passa a deter os direitos naturais transferidos pelo pacto. Afirma, nesse sentido:

[...] é como se cada homem dissesse a cada homem: Cedo e transfiro meu direito de governar-me a mim mesmo a este homem, ou a esta assembleia de homens, com a condição de transferires a ele teu direito, autorizando de maneira semelhante todas as suas ações. Feito isto, à multidão assim unida numa só pessoa se chama Estado [commonwealth], em latim civitas. (HOBBES, 1997, p. 144).

Ressalte-se, entretanto, que Hobbes impõe limites à transferência, ligados à razão mesma de criação do Estado, ou seja, a preservação da vida, num sentido fisiológico. Se os homens em estado de natureza estão em uma guerra de todos os homens contra todos os homens (HOBBES, 1997, p. 109), levando uma vida "[...] solitária, pobre, sórdida, embrutecida e curta" (HOBBES, 1997, p. 109), o Estado não poderá se furtar à função precípua para a qual foi criado, a saber, a de garantir a vida instituindo a paz - aqui entendida como ausência de guerra de todos contra todos (HOBBES, 1997, p. 109). Daí que, mesmo havendo transferência do direito natural de cada homem a um homem, ou a uma assembleia de homens (HOBBES, 1997, p. 144), há limites ao soberano: o direito de cada homem, mesmo em face do poder do Estado, "[...] de evitar a morte, os ferimentos ou o cárcere." (HOBBES, 1997, p. 119).

A paz como ausência de guerra é conceito preciso no texto do Leviatã, o que pode dar um parâmetro, por contraste, de como Espinosa se posiciona em face desse conceito, propondo, como se mostrará a seguir, a definição de paz como força advinda da fortaleza de ânimo (TP V 4 pp. 44-45). O conceito de paz em Hobbes, segundo o Leviatãa é apresentado no capítulo XIII da Parte I. Hobbes o define nos seguintes termos:

[...] durante o período em que os homens vivem sem um poder comum capaz de os manter a todos em respeito, eles se encontram naquela condição a que se chama guerra; [...] pois a guerra não consiste apenas na batalha, [...], mas naquele lapso de tempo durante o qual a vontade de travar batalha é suficientemente conhecida. [...] a natureza da guerra não consiste na luta real, mas na conhecida disposição para tal, durante todo o tempo em que não há garantia do contrário. Todo o tempo restante é de paz. (HOBBES, 1997, p. 109).

Portanto, para Hobbes, a paz é definida como o período em que não há o ânimo de travar batalha entre os homens, por oposição ao período em que este ânimo existe. O tempo de paz é definido por oposição ao conceito de guerra, de modo que este último é definido como sendo o período em que os homens vivem sem um poder comum que os disponha ao respeito mútuo - a commonwealth ou Estado.

Volta-se à afirmação de Espinosa de que mantém o direito natural na civitas para, após, tratar de seu conceito de paz. Esta curta passagem do início da carta (Ep. 50, p. 398) talvez possa ser esclarecida e aprofundada com a análise do Tratado político à luz dos conceitos da Ética. Para entender a questão da permanência do direito 
natural no estado civil - um direito natural que, à luz dos demais textos de Espinosa, deverá ser exercido com qualidade, como potência tendendo ao máximo e com predominância de afetos alegres -, a tese que diferenciaria Espinosa de Hobbes segundo a carta, o tema da diferença entre paz como ausência de guerra, de um lado, e paz como fortaleza do ânimo, por outro, será chave.

Fica evidente a importância dos afetos para as teses do Tratado político quando Espinosa escreve, logo no primeiro parágrafo da obra, que os afetos serão tratados por ele de forma diversa daquela que os demais filósofos os trataram (TP I 1 p. 5). Ou seja, na mesma linha argumentativa já explicitada na Ética III (E III Pref. p. 161), não serão tratados como vícios, mas como coisas naturais (TP I 4 p.8).

Espinosa desdobrará esta importância dada aos afetos e o seu tratamento como fenômeno natural no decorrer do Político. Procurar-se-á indicar alguns pontos da obra em que fica evidente a importância dos afetos acima apontados para forjar a política da cidade ou seu avesso, isto é, um grau quase zero de potência dos súditos que faz que se possa apontar para o fim da política, da cidade, isto é, para a situação em que aquilo que há é um deserto de potências individuais - uma cidade como a narrada por Murilo Rubião no conto 'A cidade '. Deserto de potências individuais, ou seja, algo que está próximo de um grau zero de intensidade do corpo e da mente ao se observar cada homem na civitas. Portanto, situação, para os súditos-cidadãos, avessa ao que Espinosa entende como sendo a razão de ser da cidade. Sua razão de ser, ou seja, instituição da paz na cidade como vis ou força dos seus constituintes, os súditos-cidadãos.

No parágrafo segundo do capítulo quinto do Político, Espinosa estabelece que a finalidade do estado civil no imperium é "[...] a paz e a segurança de vida [...]" (TP V 2 p. 44). E, pouco depois, diferencia um imperium sem guerra daquele que está em paz. De fato, escreve que "[...] a paz não é ausência de guerra, mas virtude que nasce da fortaleza de ânimo [...]". E complementa: "[...] aquela cidade cuja paz depende da inércia dos súditos, os quais são conduzidos como ovelhas, para que aprendam só a servir, mais corretamente se pode dizer uma solidão do que uma cidade." (TPV 4 pp. 44-45).

Paz e segurança de vida como finalidades do imperium (TP V 2 pp. 43-44). Paz como virtude que nasce da fortaleza de ânimo. Com tais conceitos Espinosa faz a ponte entre direito como potência, afetos, cidade, política e o conceito de paz. Desdobra-se a seguir este ponto, esclarecendo a tese de que a paz é fortaleza de ânimo dos súditos, não ausência de guerra.

A cidade é forjada precisamente para ser o veio no qual os homens possam ter paz e segurança. Mas, se a paz não é o mesmo que ausência de guerra, mas virtude (de vis, força, em latim) que nasce da força do ânimo, há que se levar em conta o tipo de afeto predominante que a cidade determina nos súditos.

Todos os afetos derivam dos três primários - desejo, alegria, tristeza -, como Espinosa mostra na Ética, e dos quais todos os demais são manifestações (E III P 11 Esc p. 177). O par esperança-medo é que vem a ser 
cessada a dúvida, segurança ou desespero, afetos mais estáveis. Esta deriva do medo quando cessa a dúvida. Aquela deriva da esperança quando cessa a dúvida. O desespero é tristeza, diminuição da perfeição, menor intensidade de potência, uma espécie de direito natural exercido precariamente, pois com pouca intensidade ou potência. A segurança é alegria, portanto intensidade maior da potência de tal ou qual homem, direito natural deste homem sendo exercido com estabilidade e qualidade maiores.

A política éo meio pelo qual os homens podem vir a ter a alegria em seu maior grau, ou seja, a experiência dos afetos do fortalecimento de si mesmo e do fortalecimento do outro - os afetos firmeza e generosidade. De fato, se os homens apenas se conduzissem pela razão, a fortaleza de ânimo seria um afeto experimentado por todos, pois necessariamente todos concordariam entre si (E IV P 35 Dem p. 303). Mas como é raro que isto ocorra, isto é, que os homens se conduzam pela razão (E IV P 35 Esc p. 303), a política é a astúcia institucional que leva à concórdia, isto é, o canal possibilitador do exercício adequado - real - do direito natural e do cultivo, consequentemente, dos afetos alegres. A cidade é o local em que tais afetos podem vir a existir com maior frequência nos homens, mas não sempre, visto que, caso se conduzissem pela razão, não seria necessária a política, nem a cidade.

Por isso Espinosa afirmará, no passo seguinte ao movimento cidade-solidão (TP V 4 p. 45), que a multidão - multiplicidade de desejos ou receios articulados à potência comum, na definição de Diogo Pires Aurélio (AURÉLIO, 2000, p. 275) - subjugada conduz-se mais pelo medo, ao passo que a multidão livre se conduz mais pela esperança (TP V 6 p. 45). Afirma Espinosa, para concluir este movimento argumentativo, que "[...] aquela [a multidão livre, que se conduz mais pela esperança que pelo medo] procura cultivar a vida, esta [a multidão subjugada, que se conduz mais pelo medo que pela esperança] procura somente evitar a morte [...]." (TP V 6 p. 45). A multidão que procura cultivar a vida é aquela que sustenta um tipo de poder soberano que cria instituições - o direito civil da cidade - propiciadoras de um imaginário afetivo de presente e futuro seguros. Neste imaginário, presente nas mentes dos membros da cidade e emulado pelos desejos desses mesmos membros, via imitação afetiva, os afetos predominantes são os derivados da alegria. Por isso a vis (a virtude como potência ou força) constitutiva do conceito de paz espinosano nasce da fortaleza de ânimo. Somente súditos que se reconhecem no que o poder soberano da cidade faz por eles - pois o direito civil vem, neste caso, do "[...] decreto comum da cidade [...]" (TP V 4 p. 45) - podem viver na paz entendida como situação em que os súditos-cidadãos têm alto grau de potência. Não vivem, pois, subjugados pelo soberano, mas constituem, tomam parte nas decisões da cidade e procuram estimular instituições que capilarizem afetos alegres no interior do corpo político.

O medo, por outro lado, é o afeto que, se estimulado pelo poder soberano, poderá se estabilizar, nas mentes dos homens, como desespero. Afeto triste, no qual a dúvida acerca do medo antes sentido cessa, o desespero é o retrato de uma cidade cujos súditos não têm ânimo, virtude, potência. É a cidade do conto 
analisado. A intensidade das potências individuais é cerceada pelo medo e pelo desespero. Súditos "como ovelhas" (TP V 4 p. 45) geram não a cidade, mas o deserto, termo que, segundo Laurent Bove em nota à sua revisão da tradução de Émile Saisset, indicaria uma palavra atribuída a Galgacus, chefe caledoniano (Caledônia é a atual Escócia) que resistiu à invasão romana. Galgacus teria dito, sobre os conquistadores, que faziam um deserto onde diziam ter estabelecido a paz (BOVE, 2002, p. 162).

"Súditos como ovelhas" é sinônimo de intensidades de direitos naturais individuais que gravitam em torno do grau zero de potência. Se a política é o meio para que os direitos naturais de cada um não sejam apenas opinião (TP II 15 p. 19), a cidade que institui o medo e o desespero como formas de garantir a paz não podem ser propriamente o local da política, nem podem ser adequadamente chamadas de cidade, mas de deserto ou solidão.

Assim, pode-se afirmar, agora com mais clareza, que a afirmação de Espinosa a Jarig Jelles na Carta 50, de que mantém sempre o direito natural, traz muitas consequências para o tipo de cidade que é pensada por Espinosa, bem como para o conceito de paz como vis que decorre da fortaleza de ânimo.

$\mathrm{Na}$ hipótese aqui levantada, trata-se de um conceito de política (e de cidade) que estabelece uma fina relação entre três instâncias que devem ser pensadas em conjunto. A antropologia espinosana, fundada em uma concepção de homem como grau de potência. Certa concepção do que sejam os afetos, isto é, transição de potência de um mais a um menos, até um limite, e vice-versa. E, por fim, o paradoxo de uma potência do poder soberano da cidade que deve estimular o medo à lei visando à segurança como afeto alegre predominante no corpo social.

Se assim não for, tem-se o que Espinosa chamou, ao tratar da paz duradoura e miserável do imperium turco (TP VI 4 p. 49), de barbárie, servidão e isolamento.

\section{CONCLUSÃO}

Por meio dos conceitos espinosanos, após a análise em minúcia do conto de Murilo Rubião, pode-se concluir que a cidade da qual fala o contista mineiro não é uma cidade, no sentido espinosano, mas o local da solidão. $\mathrm{O}$ afeto medo aparece capilarizado no corpo político de modo que todos os membros de tal configuração se relacionam tendo o outro como inimigo e o poder central como instância deflagradora desse afeto e de seu derivado, o desespero. Cariba é, nesse sentido, fio de esperança que não contamina os demais com sua indignação. Momento derrotado da política como afeto esperança, vencido pelo medo em bloco, disseminado pela cidade. Com efeito, tudo é crime, não se pode indagar, não se pode falar, e qualquer pergunta é por definição expressão da subversão. A prosa muriliana neste conto aponta para o que Espinosa chama de solidão no sentido político, agora se pode dizer com mais elementos.

E onde há deserto afetivo, isto é, medo e desespero, Estado policial e inquisidor, não há política, mas 
distopia, enfim, a paz miserável do imperium turco que muito se assemelha aos traços da cidade fantástica de Rubião.

Espinosa escreveu o Tratado político no século dezessete. Lá definiu a importância dos afetos, especialmente os alegres e sua predominância no corpo político, para a elaboração de um conceito forte de cidade. Murilo Rubião publicou sua obra, muita vez reescrita na medida em que era republicada, tamanha sua obsessão com a obra perfeita, predominantemente ${ }^{10}$ na segunda metade do século 20 . Se seu realismo fantástico descreve os absurdos do real, é fato que a cidade descrita no conto analisado não está longe de realidades do século passado e do atual. Há muito deserto e solidão, afetos tristes, medicalização da vida e parca participação política no atual século. Política de pouca intensidade, ainda que travestida de democracia formal, pode ser o que bem descreveram Espinosa outrora e Rubião em tempos mais recentes. Rubião e Espinosa devem ser tomados como lentes, literária e filosófica, respectivamente, para que melhor se enxergue o que pode estar bem à frente dos olhos.

\title{
THE FEAR AND THE CITY: NOTES ON MURILO RUBIÃO AND SPINOZA
}

\begin{abstract}
The article aims to examine the relation between fear and the concept of reverse of politics, which makes the city a desert or loneliness. This issue will be addressed through the study of a tale written by Murilo Rubião, entitled The City, as well as some Spinozian concepts that dialogue with the tale. The method is the analysis in detail of the primary sources, with the aid of commentators. The article concludes by the importance of literature and philosophy - as well as the dialogue between both areas - as areas that allow sharpen the look that makes analysis on the political issues. Specifically, the article shows, by the analysis of both authors, that fear can be a thermometer to measure the reverse of the policy or the death of the city. Both authors, in the end, prove to be powerful lenses to read the politics and the city, which points to the need for more bridges between literature and philosophy.
\end{abstract}

Keywords: Murilo Rubião. Spinoza. Affects. Fear. Politics.

\section{REFERÊNCIAS BIBLIOGRÁFICAS}

ANDERS, Günther. Kafka: pró e contra. Tradução, posfácio e notas de Modesto Carone. São Paulo: Cosac Naify, 2007.

AURÉLIO, Diogo Pires. Imaginação e Poder: Estudo sobre a Filosofia Política de Espinosa. Lisboa: edições Colibri, 2000.

BOVE, Laurent. Introduction. In: SPINOZA. Traité politique. Traduction d Émile Saisset révisée par Laurent Bove. Introduction et notes par Laurent Bove. Paris: Librairie Génélare Française, 2002.

${ }^{10}$ O 'O Ex-Mágico', seu primeiro livro publicado, é de 1947. 
CARONE, Modesto. O realismo de Franz Kafka. Novos Estudos CEBRAP, n. 80, mar., p. 197-203, 2008.

DRUMMOND DE ANDRADE, Carlos. Carta a Murilo Rubião. Suplemento: Murilo Rubião - O Centenário do Mágico. Belo Horizonte, Secretaria de Estado de Cultura de MG, Ed. Especial.p. 3, jun. 2016.

ESPINOSA. Spinoza Opera. Ed. de Carl Gebhardt. Heidelberg: Carl Winter, 4 vols, 1972 [1 a ed. 1925].

Ética. Tradução de Tomaz Tadeu. Belo Horizonte: Autêntica, 2008.

Tratado Político. Tradução, introdução e notas de Diogo Pires Aurélio. São Paulo: Martins Fontes, 2009.

Tratado Teológico-político. Tradução, introdução e notas de Diogo Pires Aurélio. São Paulo: Martins Fontes, 2003.

Correspondencia. Introducción, traducción, notas e índices de Atilano Dominguez. Madrid: Aliança editorial, 1988.

HOBBES. Leviatã. Tradução de João Paulo Monteiro e Maria Beatriz Nizza da Silva. São Paulo: abril Cultural, 1997 (Coleção Os Pensadores).

RICOEUR, Paul. A Metáfora Viva. Tradução de Dion Davi Macedo. São Paulo: Loyola, 2005.

RUBIÃO, Murilo. Obra Completa. São Paulo: Cia. das Letras, 2016.

WERNECK, Humberto. A Aventura Solitária de um Grande Artista. Suplemento: Murilo Rubião - O Centenário do Mágico. [Publicado originalmente em Revista Planeta, N 25, São Paulo, Set. 1974]. Belo Horizonte, Secretaria de Estado de Cultura de MG, Ed. Especial. p. 3, jun. 2016.

Trabalho enviado em 25 de agosto de 2016.

Aceito em 31 dejaneiro de 2017. 